\title{
The Fruticose Lichens in the Forest Tahura (Taman Hutan Raya) R. Soeryo, East Java
}

\author{
Miftahul Jannah $^{1)^{*}}$, Dwi Anggorowati Rahayu ${ }^{2)}$, Murni Saptasari ${ }^{3)}$, Ludmilla Fitri Untari ${ }^{4)}$ \\ ${ }^{1)}$ Laboratory of Biology, Department of Biology, As-syafi iyah Islamic University, Jakarta, Indonesia \\ ${ }^{2)}$ Laboratory of Animal Taxonomy, Department of Biology, Surabaya State University, Surabaya, Indonesia \\ ${ }^{3)}$ Laboratory of Plant Taxonomy, Faculty of Mathematics and Natural Sciences, Malang State University, Malang, \\ Indonesia \\ ${ }^{4)}$ Laboratory of Plant Taxonomy, Faculty of Biology, Gadjah Mada University, Yogyakarta, Indonesia. \\ *Email: miftahuljannah.fst@uia.ac.id
}

\begin{abstract}
A taxonomic study of the fruticose lichens in the forest of Tahura (Taman Hutan Raya) R. Soeryo had been conducted based on morphological, anatomical and chemical characters. In this research involved a method of descriptive explorative and the aim of this research is to identify and determine of fruticose lichens in the forest of Tahura R. Soeryo. Eleven species of fructicose lichen are reported for the firt time from the forest of Tahura R. Soeryo. They are Evernia prunastri, Ramalina calicaris, Teloschistes flavicans, Usnea glabrescens, $U$. subfloridana, $U$. Ceratina, $U$. floridana, $U$. hirtaand three species were found as new records in Java are $U$. esperantiana, $U$. flammea, and $U$. strigosa. Taxonomic descriptions and figures are presented in the article.
\end{abstract}

Key word:Lichen, new records, R. Soeryo, taxonomy

\section{Lichen Tipe Fruticose di Tahura (Taman Hutan Raya) R. Soeryo, Jawa Timur}

\author{
Miftahul Jannah ${ }^{1{ }^{*}}$, Dwi Anggorowati Rahayu ${ }^{2)}$, Murni Saptasari ${ }^{3)}$, Ludmilla Fitri Untari ${ }^{4)}$ \\ ${ }^{1)}$ Laboratorium Biologi, Prodi Biologi, Universitas Islam As-syafi iyah, Jakarta, Indonesia \\ ${ }^{2)}$ Laboratoium Sistematik Hewan, Prodi Biologi, Universitas Negeri Surabaya, Surabaya, Indonesia \\ ${ }^{3)}$ Laboratorium Sistematik Tumbuhan, Fakultas MIPA, Universitas Negeri Malang, Malang, Indonesia \\ ${ }^{4)}$ Laboratorium Sistematik Tumbuhan, Fakultas Biologi, Universitas Gadjah Mada, Yogyakarta, Indonesia \\ *Alamat korespondensi: miftahuljannah.fst@uia.ac.id
}

ABSTRAK

Penelitian taksonomi lichen tipe fruticose di hutan Tahura (Taman Hutan Raya) R. Soeryo berdasarkan karakter morfologi, anatomi, dan uji kimia. Penelitian ini merupakan deskriptif eksploratif yang bertujuan untuk mengidentifikasi dan menentukansetiap spesies lichen tipe fruticose hutan Tahura $R$. Soeryo. Telah dilaporkan pertama kali sebelas spesies lichen tipe fruticose dari hutan Tahura R. Soeryo, yaitu Evernia prunastri, Ramalina calicaris, Teloschistes flavicans, Usneaglabrescens, $U$. subfloridana, U. Ceratina, $U$. floridana, $U$. hirtadan tiga spesies ditemukan sebagai catatan baru di Jawa yaitu $U$. esperantiana, U. flammea, dan $U$. strigosa . Deskripsi taksonomis dan gambar disajikan dalam artikel ini.

Kata Kunci: Catatan baru, lichen, R. Soeryo, taksonomi

\section{INTRODUCTION}

The diversity data of crustose [1] and foliose [2,3] lichen was previous reported, but fruticose lichen from Tahura R. Soeryo has never been reported. Lichens has a big diversity in this forest, however, people pay very small attention in this subject, which is had right now that is still neglected. lichens is a very potential ecosystem.Lichens have been identified as valuable indicators of environmental quality
[4].This rich diversity of lichen indicates good forest health.

Lichens can also be very usefull,asmedicine, antibiotic, antimutagenic, cosmetic [5,6] and pesticide [7].Deforestation is a major enviromental issue which may cause disappearance of many lichen species without being studied. Lichen of species information as competely is very important to utilization. Therefore, we had conducted a lichen taxonomical research in purpose to identify of 
fruticose lichens in Tahura R. Soeryo. By studying and knowing lichens species in Tahura we hope students, college students, and society,to know diversity specious of lichens conserve it.

\section{METHODS}

This research is descriptive explorative was conducted from December- January 2016, and using the descriptive explorative method. The identificationbased on character of determining the of the thallus are colour, shape, type, branched, medulla; the presence or absence of apothecia, soredia, soralia, isidia, fibril, papillae, the color and type of rhizineand chemical tested. The chemical color tests used are $\mathrm{P}($ Phenylenediamin), $\mathrm{K} \quad$ (Potassium hydroxide), and $\mathrm{C}$ (Calcium hypoclorite). The identification of mycrocrystals used various reagents i.e. GAW $\left(\mathrm{H}_{2} \mathrm{O}\right.$ :glycerol:ethanol = 1:1:1), GE (acetic acid:glycerol =1:3), An (aniline:glycerol:ethanol $=1: 2: 2)$, dan oT $(0-$ toluidine: glycerol: ethanol $=1: 2: 2$ ).

\section{RESULTS AND DICUSSION}

The fruticose lichen in the forest of TahuraR. Soeryo, Batu, East Java consist of three families and 11 species. In this research the Family Parmeliaceae is the most common with ninespecies being identified. Detailed features comprising of species isprovidedbelow.

Teloschistes flavicans (Sw.)Norm.This lichen belongs to Teloschistaceae family. Thallus is caespitose or prostrate, orange yellowish up to $4 \mathrm{~cm}$ long with highly branched, rather flattened, solid, claw shaped, irregular branched, with grey soredia scattered, rhizine absent and without apothecia (Figure 1). The chemical test in medulla are $\mathrm{C}-, \mathrm{K}+$ red, $\mathrm{P}+$ red.

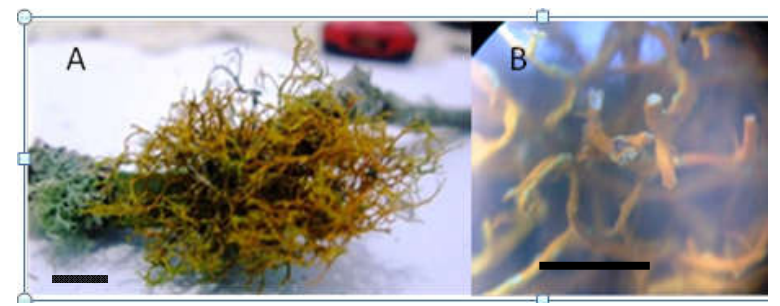

Figure 1. Teloschistes flavicans, A. Morphology of thallus, B. Solid \& Caespitose. Scales: $0.5 \mathrm{~mm}$

\section{Ramalina calicaris (L.) Fr. Fries, Sched,} Critic. This lichen belongs to Ramalinaceaefamily. Thallus cartilaginous, green up to $3 \mathrm{~mm}$ broad, long with narrow divided branches, flattened, yellowish light brown apothecia, one septate spora and irregular branched (Figure 2).Chemical test in medulla are $\mathrm{C}-, \mathrm{K}-, \mathrm{P}-$.

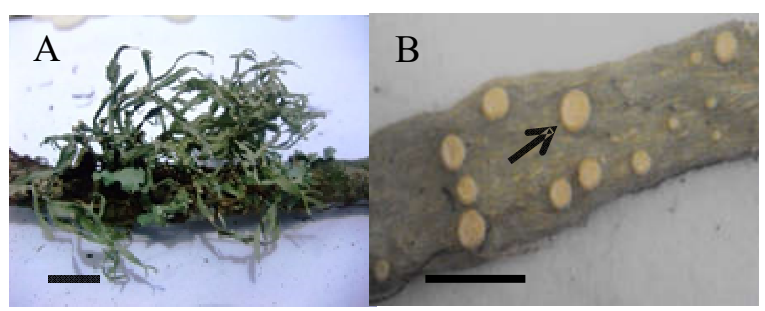

Figure 2. Ramalina calicaris,A. Morphology of thallus, B. Apothecia. Scales: 0.5 $\mathrm{mm}$

Evernia prunastri. This lichen belongs to Parmeliaceae family. Thallus greyish green, flattened, rhizineblack simpleand toward the thalus, dichotomous branches, with soredia grayish green and isidia, without apothecia (Figure 3).Chemical test in medulla are $\mathrm{C}-, \mathrm{K}$-, $\mathrm{P}+$ red.

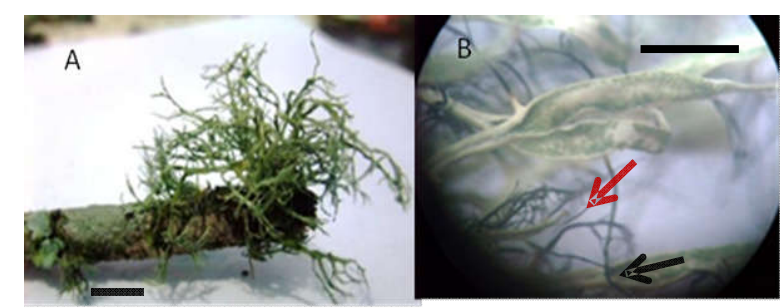

Figure 3. Evernia prunastri,A. Morphology of thallus, B. Rhizine (black line) \& Soredia (red line). Scales: $0.5 \mathrm{~mm}$

Usnea esperantiana P. Clerc. This lichen belongs to Parmeliaceae family. Thallus shrubby, grey green, with green soredia, tufted, base pale to light brownish, coarse,sausageshaped, hollow, perforated, papillae small, branchlets rather sparse, fibril present, without apothecia and isidia, medulla loose (Figure 4). Chemical test in medulla are $\mathrm{C}-, \mathrm{K}+$ yellow, $\mathrm{P}+$ red, contain salazinic acid and stictic acid.

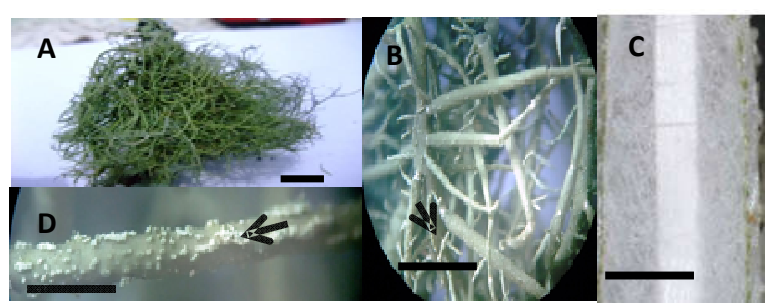

Figure 4. Usnea esperantiana, A. Morphology of thallus, B. Fibril, C. Medulla, D. Soredia. Scales: $0.5 \mathrm{~mm}$

Usnea strigosa (Ach.) Eaton. This lichen belongs to Parmeliaceae family. Thallus shrubby, base concolour (black and brown), 
tufted, branches moderately papillate, with grey soredia, soralia absent, short fibril, apothecia lacking, and medulla dense (Figure 5). Chemical test in medulla are $\mathrm{C}-, \mathrm{K}-, \mathrm{P}_{-}$, contains diffractaic acid.

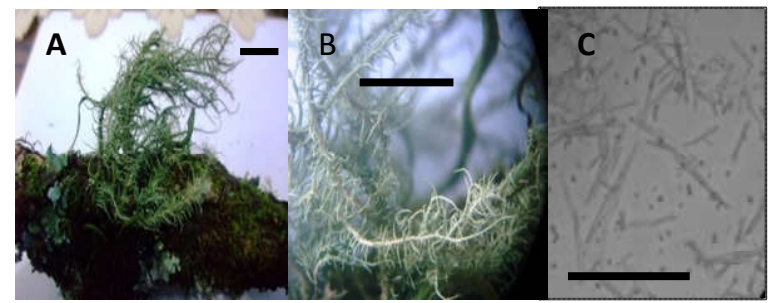

Figure 5. Usnea strigosa, A. Morphology of thallus, B. Fibril, C. Diffractaic acid. Scales: $0.5 \mathrm{~mm}$

Usnea subfloridana Stirt. This lichen belongs to Parmeliaceae family. Thallus shrubby to subpendent, base black, bushy, hollow, erect, main branches coarse with small spines, stout central axis, with green isidia and soredia, soralia convex, wart-like nodules lacking, fibril and papillae present, without apothecia, medulla dense (Figure 6).Chemical test in medulla are $\mathrm{C}-, \mathrm{K}+$ red, $\mathrm{P}+$ yellow to orange-red, contain squamatic acid and thamnolic acid.

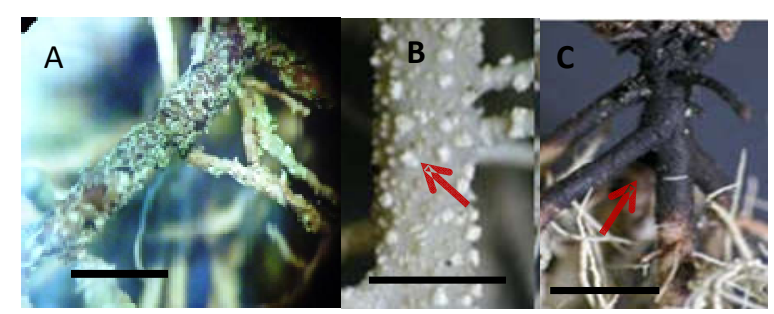

Figure 6.Usnea subfloridana,A. Soredia, B. Soralia, C. Base black. Scales: 0.5 $\mathrm{mm}$

Usnea ceratina Ach.This lichen belongs to Parmeliaceae family. Thallus shrubby, solid, with green soredia, fibril and papillae present, irregular branches, consist of relatively few main branches with some subbranches, and constriction at intervals along the main branches, medulla dense, with strawberry pink pigmentation medulla (Figure 7). Chemical test in medulla are $\mathrm{C}-, \mathrm{K}-, \mathrm{P}+$ red, contain barbatic and squamatic acid.

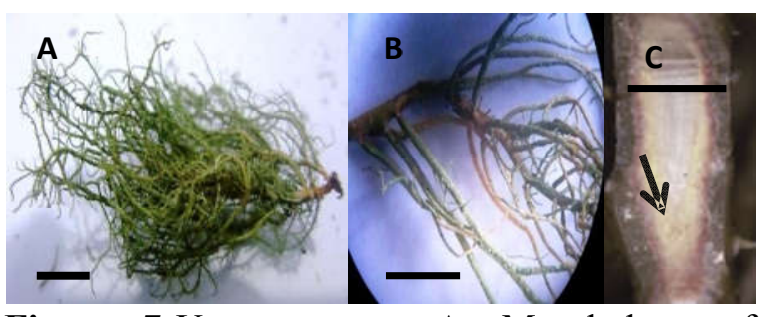

Figure 7.Usnea ceratina,A. Morphology of thallus, B. Fibril , C. Pigmentation in the medulla. Scales: $0.5 \mathrm{~mm}$

Usnea glabrescens (Nyl. ex Vain.) Vain.This lichen belongs to Parmeliaceae family. Thallus subpendent with black base, hollow, bushy, without isidia and soredia, soralia rounded and green, apothecia absent (Figure 8).Chemical test in medulla are C -, K-, $\mathrm{P}+\mathrm{red}$, contain norstictic acid.

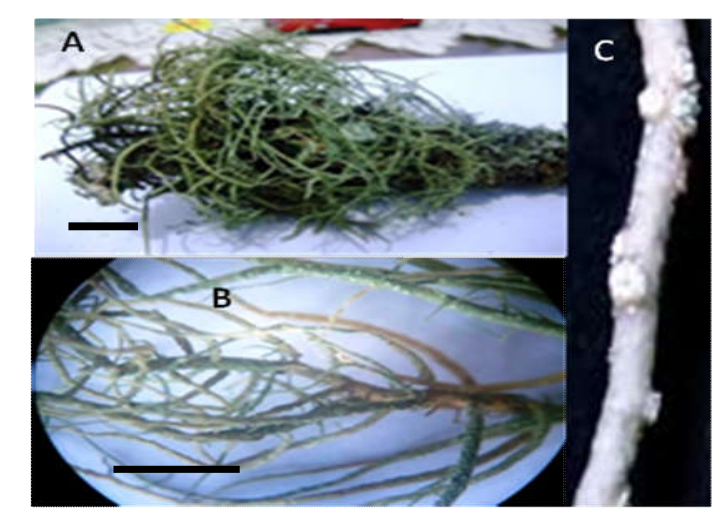

Figure 8. Usnea glabrescens, A. Morphology of thallus, B. Fibril, C. Soralia. Scales: $0.5 \mathrm{~mm}$

Usnea florida (L.) F. H. Wi. This lichen belongs to Parmeliaceae family. Thallus shrubby,soft, bushy, erect, hollow, with soredia and isidia, soralia absent, apothecia present, the main branches coarse with warth and small spine, a stout central axis, and medulla dense (Figure 9).Chemical test in medulla are C -, K-, $\mathrm{P}+$ red, contain thamnolic acid.

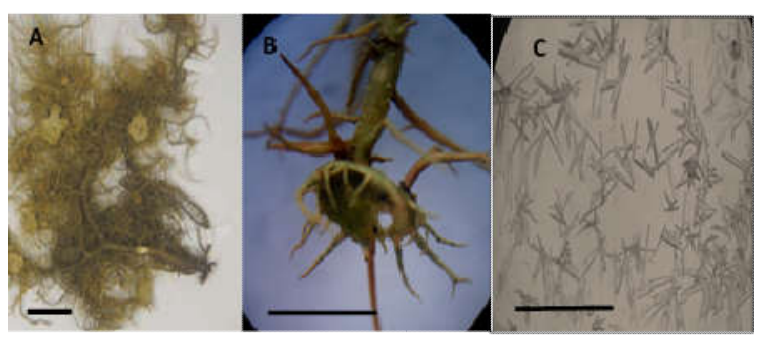

Figure 9.Usnea florida, A. Morphology of thallus, B. Apothecia, C. Thamnolic acid. Scales: $0.5 \mathrm{~mm}$ 
Usnea flammea Stirt. This lichen belongs to Parmeliaceae family. Thallus subpendent, base brownish, hollow, irregular and little branched, fibril present, with green soredia, rare soralia and isidia, apotheciaabsent, and medulla dense (Figure 10). Chemical test in medulla are $\mathrm{C}-, \mathrm{K}+\mathrm{red}, \mathrm{P}+$ red, contains stictic acid.

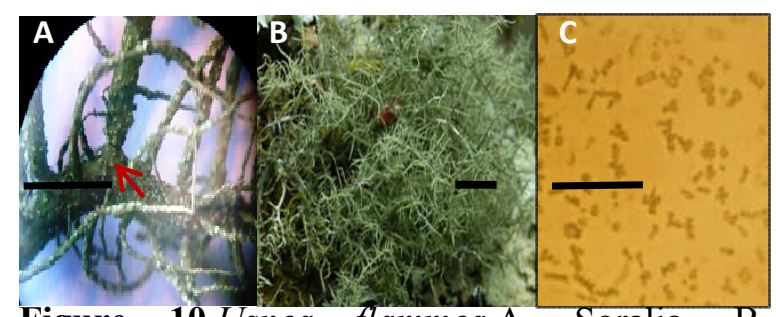

Figure 10.Usnea flammea, A. Soralia, B. Morphology of thallus, C. Stictic acid. Scales: $0.5 \mathrm{~mm}$

Usnea hirta (L.) F.H. Wigg.This lichen belongs to Parmeliaceae family. Thallus shruby, yellowish green, hollow; soredia, isidia and soralia present, fibril present, papillae absent, apothecia absent,eroded, axis narrow, the main branched are ridged and especially the tips, apothecia absent, medulla loose (Figure 11).Chemical test in medulla are $\mathrm{C}-, \mathrm{K}+$ red, $\mathrm{P}$ + red, contains norstictic acid.

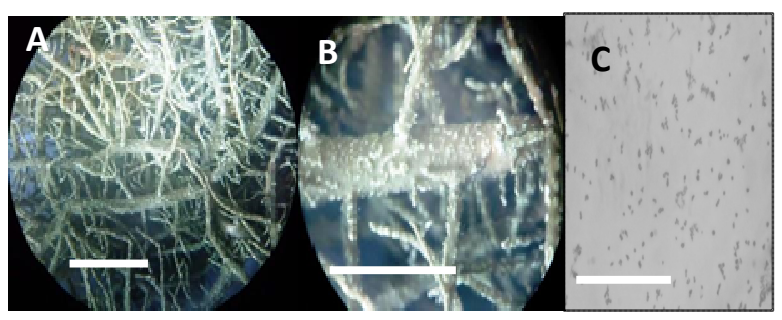

Figure 11.Usnea hirta, A. Morphology of thallus (fibril), B. Soralia, C. Norstictic acid. Scales:0.5 mm

\section{CONCLUSION}

Eleven species of fruticose lichens have been found in this study. This research also found three new record species namelyUsnea strigosa, U. flammea, and U. esperantiana in Java, from previous study Usnea in Java [8, 9].The results of this study are expected to be the basis for further fruticose or another lichen research.

\section{ACKNOWLEDGEMENTS}

The authors are thankful to Heru Cahyono, S.Si. and Devi A.M., S.Si. who acted as field guide and informant during the survey in forest.

\section{REFERENCES}

[1]. Jannah M, Untari LF (2019)Taxonomy of crustose lichens in the forest of Tahura R. Soeryo, Batu, East Java.BIOTROPIC3(1): 2580-5029.

[2]. Jannah M, Rahayu DA, Mahadi DM, Sapta Sari M, Untari LF (2009)The diversity of foliose lichen in the forest of Tahura R. Soeryo, Batu, East Java.In Proceeding of the International Conference of Biological Science, Gadjah Mada University, Yogyakarta, pp. 16-17.

[3]. FatmaY, MahanalS, SariMS (2017) Keanekaragaman Familia Physciaceae dan Lobariaceae di Taman Hutan Raya Raden Soeryo sebagai bahan ajar pada mata kuliah Mikrobiologi.Jurnal Pendidikan2(2): 179185.

[4]. Kricke R,Loppi S (2002) Bioindication: The I.A.P. ApproachIn: PL Nimis, C Scheidegger, PA Wolseley (eds)Monitoring with lichens- monitoring lichens. Kluwer Academic Publishers,Dordrecht, pp. 21-37.

[5]. Nash HT (1996)Lichen Biology.Combridge University Press, Arizona.

[6]. Negi HR(2003) Lichens: A valuable bioresource for environmental monitoring and sustainable development.Resonance8(1): 51-58.

[7]. Dayan FE,Romagni JG (2001) Lichens as apotential source of pesticides.PesticideOutlook12(6):229-232.

[8]. Zahlbruckner A (1956)Flechtenflora von Java.Willdenowia Bd. 1, H. 3: 433-528.

[9]. Noer IS, Ramlan A, Subarnas A, Sutedja E(2013) Karakterisasi dan kekerabatan Janggot Kai (Usnea spp.) di Priangan.Indonesian Journal of Applied Sciences3(2): 66-73. 